\title{
Utilization of Library Resources Among Graduate Students of Leyte Normal University (LNU)
}

\author{
L.F. Alcober
}

\section{ABSTRACT}

This study assessed the utilization of the resources of the Leyte Normal University Learning Resource Center by the graduate students enrolled in various graduate curricular program offerings for the AY 2018, 2019, and 2020. The assessment concentrated on the subject area, borrowers per program, professional journals and magazines, and databases, e-books, and internet connectivity during the academic years 2018, 2019, and 2020. In this context, utilization was focused. Utilizing the survey design, statistically treated data showed that books are commonly borrowed resources and that borrowing frequency is dependent on the enrollment of a curricular program offering. Bulk of borrowers were recorded for AY 2018 and 2019. Taking things holistically, the general circulation of the library is deemed helpful to its immediate users. An intervention plan was prepared further to promote the richness of the resources in the library and consequently attract more users.

Keywords: Graduate Students, Library, Library Resources, Utilization

Published Online: January 28, 2022

ISSN: $2736-4534$

DOI: $10.24018 /$ ejedu.2022.3.1.218

L.F. Alcober

Leyte Normal University, Philippines.

(luvimindaalcober@1nu.edu.ph)

\section{INTRODUCTION}

Academic repositories are jewels of school libraries. These resources are usually kept in the circulation section. Circulation, in this context, refers to the process of checking in and out of academic resources in a library. This process allows users to bring these resources outside the circulation premises. This contention is in consonance with the first two "laws of library science; books are for use, and every reader his/her book" (Reitz, 2014; Kumar, 2020). Libraries exist inordinately to help students be able to access their vast resources. It is said that these resources become helpful if they can respond to the needs of library patrons. Thus, the availability of these resources creates an empowering environment to maximize its usage for information search using an effective system and technologies. Like any other library worldwide, the Leyte Normal University Learning Resource Center (LNU-LRC) is committed to serving its stakeholders, primarily the students. Therefore, the library's circulation section is reserved primarily for its students and offers lending policies, organized collections, and assistance. In addition, these services are extended through face-to-face services and telephone, e-mails, chat, and instant messaging (IM) references. In the view of the continuous improvement (CI) principle, which regards the system's operation as fundamental, it is thus imperative to assess the utilization of all the library materials of the LNU-LRC by the graduate students in the university. Therefore, this study looks into an in-depth assessment of the utilization records from the library's borrowing of materials, grouped by subject, course, category of collections, borrowers, and school year. Furthermore, this study hoped to determine if these learners patronize the library given the busy lifestyle and the availability of a vast array of search engines useful for academic undertakings.

This study used the Demand Theory of Lionel McColvin as its theoretical anchor. The basic tent of the theory is that a library's collection must be grounded on the demands of the library users. The use of this theory is deemed appropriate in this study since library managers must acquire resources that promote the development, enrichment, and response to the educational needs of its immediate users. Therefore, academic libraries select resources commensurate to the needs of the students and the faculty, and other stakeholders with interest in the academe. Overall, it is essential to preidentify the vital resources meaningful and valuable to its users (Gardner, 1981).

\section{REVIEW OF RELATED LITERATURE}

There are various researches focused on the library and its utilization. A library that has no users is a malfunctioning library. Therefore, the utilization of library resources is The authors of the accepted manuscripts will be given a copyright form and the form should accompany your final submission.

The borrowing of library materials is a concern of academic libraries because it provides data on the library's goals. The use of library resources is an instrument that enables the management to think of its functions of serving library clients (Onifade et al., 2013). Thus, user studies are 
regarded as an authentic device for the evaluation of libraries and their services. The study of Onifade et al. (2013) revealed that postgraduate students preferred to use internet sources than print resources, while Lateef et al. (2013) found in their study that students did not regularly utilize their library's resources because there were no updated resources, and the materials in the library do not answer their information needs.

As such, Komolafe (2011) argued that identifying the resources patronized by the graduate students to assess the utilization, availability of resources, and formats must be underscored. Meanwhile, literature also exists as regards the purpose of the utilization of libraries. Shrestha (2008), for example, concluded that students used the library regularly for studying purposes in her study. Onuoha and Subair (2013), on the other hand, said that students who visit the library to borrow learning, connect to the internet, photocopy, and check the latest service offerings.

However, Lateef et al. (2013) said that students visit the library for relaxation between lectures and meet their classmates and friends. Finally, literature on the utilization of library resources also abound. For example, Raza et al. (2011) concluded in their study that Indian students are aware of the resources and services of libraries and use them as course materials. Postgraduate Greek students, however, according to Saiti (2008), preferred the internet as the primary provider of information because it is accessible and provides credible information. Finally, Kumah (2015) said that postgraduate students visit the library because it offers an ideal space to study, and they enjoy the services provided to them.

\section{Methodology}

This study utilized the survey method as its research design. According to Pinsonneault and Kraemer (1993); and Salant and Dillman (1994), this method is considered a means for gathering information relative to a large population's characteristics, actions, or opinions to carry out assessment needs, evaluate demand, and examine impacts. Therefore, the design is fit for this undertaking as it provided information and identified the circulation trends of all the resources of the LNU-LRC. Data were collected from the book circulation statistics stored in the LNU-LRC library Athena, an automation system. The data collection was focused on the highest circulated books and patrons with the highest checkouts. Descriptive statistical tools were then utilized for its analyses.

\section{RESULTS}

Results of the findings showed that books in Education (491), Management (464), and Research (437) were frequently used by the graduate students of LNU for SY 2017-2018. However, in SY 2019-2020, the highest numbers of books borrowed by students were on Management (439), Education (390), and Research (392). In Academic Year 2018, 2019, 2020, though, the utilization of these resources significantly declined due to a decrease in the students' population. Interestingly, data showed that the IT subject shows the lowest utilization among graduate school students. Therefore, it is safe to conclude that the number of collections per program significantly affects the utilization of materials. Interview results by the respondents showed that library users of LNU want to have stock of updated, current, and relevant library materials.

Additionally, the highest number of borrowers were from the Master in Management (M.M.) students of $21.75 \%$, M.A. Educational Management with $8.99 \%$, and M.A.T. Soc. Sci. of $7.92 \%$. On the other hand, the program with the lowest utilization was the Master's in Information Technology (MIT) students. The data further revealed that the utilization of library materials in the last three (3) School Years by the graduate school students decreased. These findings were supported by (Mutani, 2016). The researchers found that there was low utilization because the materials did not answer the students' queries. Students were looking for updated materials in the library. Another reason for low utilization was the lack of orientation among students on using the library and the number of hours in using the library.

Meanwhile, as regards the utilization of journals and magazines by graduate school students in the past three (3) school years SY 2017-2018, SY 2018-2019, and SY 20192020. Data showed that the Master in Management (M.M.) students had the highest number of users. There were 57 borrowers for professional journals and magazines in SY 2019-2020, but no borrowers of journals in S.Y. 2018-2019 and S.Y. 2017-2018. The Master of Arts in Education major in Educational Management (M.A.Ed.Mgt.) had the highest borrowers of journals and magazines of 55 borrowers in the S.Y. 2018-2019, and for the S.Y. 2017-2018, the highest number of borrowers were in the Master in English (M.E.) students with 45 borrowers.

Similarly, it also revealed that students from the Master in English (M.E), Master in Teaching English Language, and the Doctor of Arts in Language Teaching were among the highest users of journals and magazines compared to the other students of the graduate school programs. The other graduate school programs which had low utilization were from the M.A. Ed. Mgt., M.A. Pre-Elem., MPE and Ed.D. Students who did not use the Journals and Magazines were from M.A.Ed. Math, MAT Filipino, MAT Soc. Sci., M. Bio., MIT, $\mathrm{DM}$, and Ph.D. SSR. The result implies that journals and magazines were underutilized as students prefer to borrow books instead. The finding above is supported by Mwatela's 2010) study averred that lack of library and information skills contributes to the menace.

Finally, the percentage of utilization of databases and ebooks and internet/WIFI usage showed that the highest rate of users was the Master in Management (M.M.) students. The data show that students from the different graduate school programs utilized the databases and e-books available at the LNU-LRC. Further, data show that graduate students also used internet sources as their source of information. Research conducted by Kumah (2015) revealed that students use both the library's print and electronic collections. The study's findings showed that print resources positively correlated to the use of online resources. Mutani (2016) also said the use of the internet in information searching was essential among library users in this age of technology breakthrough. 


\section{Discusssions}

This study looked into the utilization of the resources of LNU-LRC by the graduate students enrolled in various graduate curricular program offerings for the academic years 2018, 2019, and 2020. In this context, utilization concentrated in the subject area, borrowers per program, professional journals and magazines, databases, e-books, and internet connectivity.

Statistically treated data showed that books are the common resource utilized by the students compared to journals and internet resources such as e-books. Borrowers or users are dependent on the enrollment of a particular curricular program offering. Bulk of borrowers were recorded in AY 2018 and 2019. The findings of this study are essential since the library is the main center where somebody looks for information. Library users will use library resources extensively if it has a rich, updated, and suitable collection. Likewise, the library is crucial in the lives of graduate students because they offer resources that could help them complete their programs in due time. Kumah's (2015) study states that graduate students considered libraries significant in e-Education and learning. Students prefer the library over the internet because the resources are already organized and updated.

\section{CONCLUSION}

Given the results of the findings, it is thus imperative that the LNU-LRC constant upgrades its resources, especially that studies such as those reported by Guarino et al. (2014), stated that the quality of services and how these services are disposed to the library users, spell out the standard of an institution. A successful library operation is gauged by factors like staff competency and balance and upgraded collection of its information resources. Luckily, the LNU management constantly upgrades the university's library resources to be accessed by both its graduate and undergraduate students.

\section{REFERENCES}

Gardner, R. K. (1981). Library collections, their origin, selection, and development. McGraw Hill.

Guarino, E., De Mesa, M., \& Chavez, N. (2014). Assessment of library holdings, services and utilization: Basis for the accreditation preparation of an engineering department [Unpublished Master's thesis]. Lyceum of the Philippines University, Batangas.

Komolafe-Opadeji, H. (2011). Use of internet and electronic resources amongst postgraduate students of a Nigerian Private University. Information Technologist (The), 8(1), 54-69. http://dx.doi.org/10.4314/ict.v8i1.72407

Kumah, C. (2015). A comparative study of the use of the library and the internet as sources of information by graduatstudents in the University of Ghana. https://www.researchgate.net/publication/286489608.

Lateef, E.B, Omotoso, A.O., \& Owalabi, K. A (2013). A survey of postgraduate students' perception of university library resources in selected Nigerian Universities. Journal of Library and Information Science, 3(1), 23-37.

Mutani, V. (2016). Utilization of library resources at Saint Augustine University of Tanzania (Main Campus) [Unpublished doctoral dissertation]. Mzumbe University. https//www.semanticsscholar

Mwatela, W. (2013). Factors influencing utilization of library services and resources: The case of University of Nairobi Mombasa Campus Library. http://erepository.uonbi.ac.

Onifade, F. N., Ogbuiyi, S. U., Omeluzor, S. U. (2013). Library resources and service utilization by postgraduate students in a Nigerian private university. International Journal of Library and Information Science, 5(9). 36-54. https://doi.org/10.5897/IJLIS2012.054

Onuoha, U. D., \& Subair, M. O. (2013). Undergraduates' use of libraries in Federal Universities in South-West, Nigeria. Journal of Research \& Method in Education, 3(5), 12-17.

Pinsonneault, A., \& Kraemer, K. L. (1993). Survey research methodology in management information systems: An assessment. Journal of Management Information Systems, 10, 75-105.

Raza, M. M., Upadhyay, A. K., and Noor, F. E. (2011). Utilization of library resources and services in the select management institute: A study. International Journal of Library Science, 3(11), 34-45.

Reitz, J. M. (2014). Dictionary for library and information science. Libraries Unlimited

Salant, P., \& Dillman, D. A. (1994). How to conduct your own survey? New York: John Wiley and Sons.

Saiti, A. (2008). Postgraduate students and learning environments: Users' perceptions regarding the choice of information sources. The International Information \& Library Review, 40(2), 94-103.

Shrestha, N. (2008). A study on students' use of library resources and selfefficacy [Master's thesis]. Tribhuvan University. 